\title{
Instytucja upomnienia, o której mowa w art. 173 k.k.w.
}

\author{
KRZYSZTOF STASIAK \\ ORCID: 0000-0001-5669-5583 \\ Katedra Prawa Karnego Materialnego i Kryminologii \\ Wydział Prawa i Administracji Uniwersytetu Gdańskiego \\ Kurator Okręgowy Sądu Okręgowego w Gdańsku
}

\section{Wprowadzenie}

Nowelizacja kodeksu karnego wykonawczego z 2011 roku $^{1}$ do systemu prawnego wprowadziła instytucję upomnienia. Określono, że sądowy kurator zawodowy będzie mógł ją stosować wobec osób, którym sąd: udzielił warunkowego zwolnienia z reszty kary pozbawienia wolności; warunkowo zawiesił wykonanie kary pozbawienia wolności; warunkowo umorzył postępowania karne; odroczył wykonanie kary pozbawienia wolności lub udzielił przerwy w jej wykonaniu. Jako powód wprowadzenia tej instytucji podano:

W przypadku odstąpienia od złożenia wniosku, o którym mowa wyżej [o odwołanie warunkowego zwolnienia, o zarządzenie warunkowo zawieszonej kary pozbawienia wolności, o podjęcie warunkowo umorzonego postępowania karnego, o odwołanie przerwy lub odroczenia kary — K.S.], sądowy kurator zawodowy zobligowany jest, zgodnie z projektowanym $\S 3$ [art. $173 \S 3$ k.k.w. - K.S.], udzielić skazanemu lub sprawcy pisemnego upomnienia. Jest to istotne novum w polskim prawie, dające sądowemu kura-

${ }^{1}$ Ustawa z dnia 16 września 2011 roku o zmianie ustawy — Kodeks karny wykonawczy oraz niektórych innych ustaw (Dz.U. z 2011 r. Nr 240, poz. 1431).

Nowa Kodyfikacja Prawa Karnego 54, 2019

(C) for this edition by CNS 
torowi zawodowemu ważne narzędzie dyscyplinujące skazanego do przestrzegania obowiązującego prawa oraz poddania się, w okresie próby, nałożonym na niego obowiązkom. Dodatkowo stwarza skazanym szansę na poprawę zachowania, bez konieczności podejmowania przez sąd odpowiednich czynności i decyzji ${ }^{2}$.

Jak wynika z zamierzeń projektodawców, instytucja upomnienia ma postać krótkiej formalnej interwencji, stosowanej przez sądowego kuratora zawodowego w sytuacji wystąpienia niektórych negatywnych zachowań u skazanego lub sprawcy. Jej celem jest zdyscyplinowanie skazanego (sprawcy) do zmiany zachowania pod groźbą negatywnych konsekwencji prawnych. Jednocześnie jest też jednym z narzędzi, które mają doprowadzić do readaptacji społecznej skazanego czy też szerzej - jego resocjalizacji.

Od wdrożenia tej instytucji minęło kilka lat. W tym okresie, w związku z jej stosowaniem, uwidoczniło się wiele problemów i wątpliwości. Niektóre z nich zostały już omówione w literaturze przedmiotu. Jednak nadal występują kwestie, które wymagają refleksji i zastanowienia. Taka diagnoza stała się dla mnie inspiracją do napisania niniejszego artykułu, który w zamierzeniu ma być próbą monograficznego ujęcia instytucji upomnienia.

\section{Stosowanie instytucji upomnienia}

Co roku wobec wielu tysięcy osób sądowi kuratorzy zawodowi stosują instytucję upomnienia. Szczegółowe dane na temat ich liczby za lata 2015-2018 przedstawia tabela 1.

Zwraca uwagę, że w ciągu tych czterech lat liczba udzielanych upomnień zmniejszyła się o blisko 55\%. Należy to przede wszystkim wiązać ze spadkiem liczby prowadzonych przez zespoły kuratorskie spraw, w których upomnienia mogą być stosowane. Przy czym w największym stopniu zmniejszyła się liczba prowadzonych spraw w związku z warunkowym zwolnieniem z reszty kary (z 58,9 do 33,6 tys., czyli o 57\%), następnie kar pozbawienia wolności z warunkowym zawieszeniem (z 334

${ }^{2}$ Uzasadnienie do rządowego projektu ustawy o zmianie ustawy — Kodeks karny wykonawczy oraz niektórych innych ustaw — druk 3961, Sejm VI kadencji, http://orka. sejm.gov.pl/Druki6ka.nsf/wgdruku/3961 (dostęp: 11.02.2019).

Nowa Kodyfikacja Prawa Karnego 54, 2019

(C) for this edition by CNS 
do 176 tys., czyli o 53\%), natomiast liczba warunkowo umorzonych postępowań karnych wzrosła o 2\% (z 5,7 do 5,8 tys.) $)^{3}$. Oznacza to, że nastąpił nieznaczny procentowy wzrost częstotliwości stosowania upomnień w przypadku spraw z warunkowym zwolnieniem z reszty kary pozbawienia wolności i warunkowym umorzeniem postępowania karnego (jak wynika z tabeli, w omawianych latach wzrósł procentowy udział tego rodzaju spraw w ogólnej liczbie udzielanych upomnień).

Tabela 1. Liczba udzielonych upomnień

\begin{tabular}{|c|c|c|c|c|c|c|c|c|}
\hline 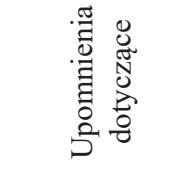 & $\begin{array}{l}n \\
\stackrel{n}{0} \\
\frac{n}{0} \\
\simeq\end{array}$ & 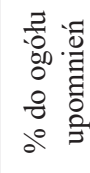 & 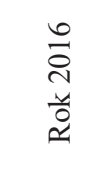 & 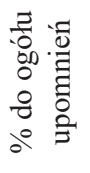 & 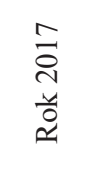 & 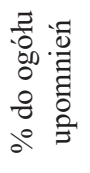 & $\begin{array}{l}\infty \\
\stackrel{0}{0} \\
\frac{4}{0} \\
\sim\end{array}$ & $\begin{array}{l}\text { 롱. } \\
0 \\
0 \\
0 \\
0 \\
0 \\
0 \\
0 \\
0\end{array}$ \\
\hline $\begin{array}{l}\text { warunkowego } \\
\text { przedter- } \\
\text { minowego } \\
\text { zwolnienia }\end{array}$ & 3116 & 18,4 & 2822 & 19 & 2222 & 20,8 & 1654 & 21,6 \\
\hline $\begin{array}{l}\text { warunkowego } \\
\text { zawieszenia } \\
\text { wykonania } \\
\text { kary }\end{array}$ & 13678 & 80,6 & 11825 & 79,6 & 8119 & 76 & 5818 & 75,7 \\
\hline $\begin{array}{l}\text { warunkowego } \\
\text { umorzenia } \\
\text { postępowania } \\
\text { karnego }\end{array}$ & 174 & 1 & 202 & 1,4 & 338 & 3,2 & 209 & 2,7 \\
\hline $\begin{array}{l}\text { ogólna liczba } \\
\text { upomnień }\end{array}$ & 16968 & 100 & 14849 & 100 & 10679 & 100 & 7681 & 100 \\
\hline
\end{tabular}

Źródło: opracowanie własne na podstawie danych statystycznych Ministerstwa Sprawiedliwości zawartych w drukach MS-S40r.

Szczegółowe dane dotyczące liczby udzielonych upomnień w stosunku do liczby prowadzonych spraw ilustruje wykres:

${ }^{3}$ Na podstawie danych statystycznych zawartych w druku MS-S40r.

Nowa Kodyfikacja Prawa Karnego 54, 2019

(C) for this edition by CNS 


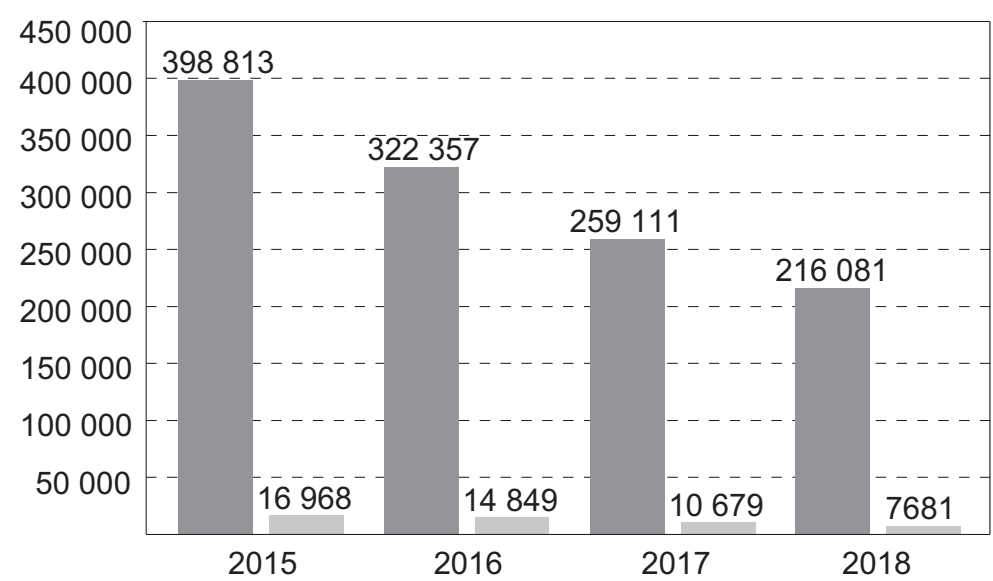

— Liczba prowadzonych spraw _ Liczba upoomnień

Rys. 1. Liczba upomnień w stosunku do liczby prowadzonych spraw

Źródło: Opracowanie własne na podst. danych statystycznych zawartych w drukach MS-S40r. Jako liczbę prowadzonych spraw przyjęto sumę stanu na koniec okresu statystycznego oraz spraw zakończonych w danym roku. W ten sposób uwzględniono wszystkie sprawy, którymi kuratorzy w danym roku się zajmowali. Uwzględniono tylko te sprawy, w których kurator mógł udzielić upomnienia.

Na podstawie wykresu można wyliczyć, że upomnienia w danym roku są stosowane w mniej więcej 4\% spraw ${ }^{4}$. Przy czym ta liczba spada od 2016 roku, gdyż w wymienionym roku wynosiła 4,61\%, w 2018 zaś już tylko 3,55\%. Nie są znane powody takiej tendencji, jednak można przypuszczać, że jednym z nich jest najprawdopodobniej ich umiarkowana skuteczność, co może zniechęcać kuratorów do częstego sięgania po to narzędzie. O tej umiarkowanej skuteczności może świadczyć fakt, iż mniej więcej w jednej czwartej spraw ${ }^{5}$ po udzieleniu upomnienia kuratorzy składają wnioski, o których mowa w art. $173 \S 3$ k.k.w. Ponieważ

${ }^{4}$ W 2015 roku było to 4,25\%, w 2016 - 4,61\%, w $2017-4,12 \%$ i w 2018 $-3,55 \%$.

${ }^{5} \mathrm{Z}$ danych statystycznych zawartych w drukach MS-S10r i MS-S10o (za lata 2015-2016) wynika, że gdy porównany liczbę udzielonych upomnień do liczby złożonych wniosków, jeśli wcześniej wobec skazanego (sprawcy) zastosowano upomnienie, otrzymamy wynik około 24\%. Zatem należy przyjąć, iż w około jednej czwartej spraw po udzieleniu upomnienia kurator sądowy składa do sądu odpowiedni do sytuacji wniosek. Nowa Kodyfikacja Prawa Karnego 54, 2019

(C) for this edition by CNS 
według stanu na koniec 2018 roku w Polsce było 2980 kuratorów zawodowych dla dorosłych ${ }^{6}$, pracujących w sądach rejonowych, zatem przeciętnie w tym okresie jeden kurator stosował upomnienie raz na pół roku.

\section{Charakter prawny upomnienia}

Na skutek nowelizacji k.k.w. z 2011 roku nastąpiła istotna zmiana konstrukcji art. 173. W jej wyniku między innymi zmodyfikowano dotychczasowe brzmienie $\S 2 \mathrm{w}$ zakresie określającym zadania sądowego kuratora zawodowego (zmieniono nomenklaturę z „zakresu działania” na „obowiązki" $)^{7}$. Zmiana ta wynikała z chęci podkreślenia obligatoryjnego charakteru czynności, o których mowa w art. $173 \S 2$ pkt 1-15 k.k.w. Wśród nich jest zawarty obszerny katalog różnego rodzaju wniosków, które kurator po spełnieniu przesłanek ustawowych jest zobowiązany składać. Wyjątkiem od tej powinności jest zaistnienie okoliczności, o których mowa w $\S 3$ i 4 art. 173. Zgodnie z nimi sądowy kurator zawodowy może odstąpić od złożenia odpowiedniego wniosku i udzielić skazanemu (sprawcy) pisemnego upomnienia, jeżeli wystąpią warunki, o których mowa w art. $156 \S 1$ i 2 lub art. 160 § 3 k.k.w. bądź art. 68 § 2 lub art. $75 \S 2$ k.k. oraz jednocześnie „przemawiają za tym rodzaj i stopień naruszenia uzasadniające przekonanie, że pomimo odstąpienia od złożenia wniosku, cele środka związanego z poddaniem skazanego lub sprawcy próbie zostaną osiągnięte".

Zatem sądowy kurator zawodowy składa do sądu odpowiedni wniosek (o zarządzenie wykonania kary, o odwołanie warunkowego zwolnienia, o podjęcie warunkowo umorzonego postępowania karnego lub o odwołanie odroczenia lub przerwy) lub udziela upomnienia, jeżeli skazany (sprawca):

1. w okresie próby rażąco narusza porządek prawny — w art. 160 $\S 3$ k.k.w, art. 68 § 2 k.k., art. $156 \S 1$ i 2 oraz art. 75 § 2 k.k. Pojęcie to zostało zdefiniowane przez podanie przykładów zachowań, które należy uznać za rażące naruszenie porządku prawnego (popełnienie inne-

${ }^{6}$ Na podstawie danych statystycznych zawartych w druku MS-S40r.

${ }^{7}$ Szerzej na ten temat K. Stasiak, Kurator sadowy organem postępowania wykonawczego, [w:] Kuratela sadowa w Polsce. Analiza system. Ksiega pamiątkowa dedykowana doktorowi Tadeuszowi Jedynakowi, red. K. Stasiak, Toruń 2018, s. 147-149. Nowa Kodyfikacja Prawa Karnego 54, 2019

(C) for this edition by CNS 
go przestępstwa niż takie, które stanowi podstawę do obligatoryjnego odwołania warunkowego zwolnienia, podjęcia warunkowo umorzonego postępowania karnego lub zarządzenia wykonania kary). W art. $160 \S 3$ k.k.w. podano jeszcze, że rażącym naruszeniem porządku prawnego jest też popełnienie przestępstwa umyślnego, jeżeli za nie orzeczono inną karę niż kara pozbawienia wolności bez warunkowego zawieszenia jej wykonania. Natomiast w art. $156 \S 1$ i 2 w żaden sposób nie wyjaśniono, co należy rozumieć przez rażące naruszenie porządku prawnego;

2. uchyla się od dozoru — art. $160 \S 3$ k.k.w., art. $68 \S 2$ oraz art. 75 $\S 2$ k.k.;

3. uchyla się od wykonania nałożonych obowiązków — art. 160 $\S 3$ k.k.w., art. $68 \S 2$ oraz art. $75 \S 2$ k.k.;

4. z powodu niewykonywania obowiązków określonych w art. 151 $\S 4$ k.k.w. - art. $156 \S 1$ i 2 ;

5. uchyla się od wykonania orzeczonych środków karnych art. $160 \S 3$ k.k.w., art. $68 \S 2$ oraz art. $75 \S 2$ k.k.;

6. uchyla się od wykonania środka kompensacyjnego — art. 160 $\S 3$ k.k.w., art. $68 \S 2$ oraz art. $75 \S 2$ k.k.;

7. uchyla się od wykonania przepadku - art. 160 § 3 k.k.w., art. 68 $\S 2$ oraz art. $75 \S 2$ k.k.;

8. uchyla się od wykonania kary grzywny — art. $75 \S 2$ k.k.;

9. skazany nie korzysta z odroczenia lub przerwy w celu, w jakim zostały one udzielone — art. $156 \S 1$ i 2;

10. sprawca nie wykonuje zawartej z pokrzywdzonym ugody art. $68 \S 2$ k.k.

Treść art. $173 \S 3$ i 4 k.k.w. w literaturze wielokrotnie była poddawana analizie. W jej wyniku doszło do wyodrębnienia kilku problemów, a niektóre z nich stały się powodem sporu naukowego, który dotyczy przede wszystkim określenia charakteru prawnego upomnienia. W tym zakresie ukształtowały się dwa poglądy. Zgodnie z pierwszym, prezentowanym przez Krzysztofa Dąbkiewicza, upomnienie nie jest decyzją ${ }^{8}$,

${ }^{8}$ K. Dąbkiewicz w tym zakresie zmienił zdanie, gdyż początkowo uznał, że upomnienia udzielone skazanemu lub sprawcy przez sądowego kuratora zawodowego są decyzją, natomiast negował możliwość ich zaskarżenia przez adresata (idem, Zaskarżalność postanowień i decyzji podejmowanych w postępowaniu wykonawczym, „Probacja” 2012, nr 2, s. 102-110).

Nowa Kodyfikacja Prawa Karnego 54, 2019

(C) for this edition by CNS 
o której mowa w art. 7 k.k.w., gdyż nie spełnia wymagań, które w literaturze $\mathrm{w}$ kwestii decyzji zostały określone (zgodnie z przyjętym rozumieniem tego pojęcia decyzja to każdy akt prawny o charakterze indywidualnym i konkretnym, rozstrzygający sprawę konkretnego skazanego w części lub w całości, lub też w inny sposób kończący sprawę ${ }^{9}$ ), lecz jest czynnością materialno-techniczną. Przy czym czynnością taką jest „czynność podjęta przez odpowiedni organ, która przyznaje, stwierdza albo uznaje uprawnienia lub obowiązki wynikające z przepisów prawa"10. Zdaniem tego autora upomnienie jest niczym więcej jak skierowanym do skazanego pisemnym poleceniem określonego zachowania, „które wynika z treści wydanego wobec skazanego lub sprawcy orzeczenia sądu - w istocie jest rodzajem pouczenia"11. Zdaniem Krzysztofa Dąbkiewicza upomnienie nie ma charakteru „władczego, nie rozstrzyga (nie ingeruje) o prawach skazanego (sprawcy), stanowi wyłącznie skierowane do skazanego polecenie przestrzegania prawa i postępowania zgodnego z treścią obowiązków wynikających z orzeczenia sądu"12.

Zgodnie z drugim poglądem upomnienie zastosowane przez sądowego kuratora zawodowego jest decyzją, o której mowa w art. 7 k.k.w. Pogląd tej jest reprezentowany przez większość przedstawicieli doktryny zajmujących się tą problematyką. Można tutaj wymienić Kazimierza Postulskiego $^{13}$, Rafała Skręta i Sławomira Stasiorowskiego ${ }^{14}$. Uzasadniając to stanowisko, w literaturze przytoczono argumenty:

${ }^{9}$ K. Postulski, Decyzja kuratora $w$ postepowaniu karnym wykonawczym, „Probacja” 2012, nr 2, s. 70; T. Kalisz, Skarga na decyzje organów wykonawczych. Tryb skargowy $z$ art. 7 k.k.w., „Nowa Kodyfikacja Prawa Karnego” 7, 2001, s. 154; S. Lelental, Kodeks karny wykonawczy. Komentarz, Warszawa 2010; K. Dąbkiewicz, Zaskarżalność postanowień..., s. 105.

${ }^{10}$ K. Dąbkiewicz, Kodeks karny wykonawczy. Komentarz, Warszawa 2015, Komentarz do art. 173, Nb 13. Podobnie idem, Kilka uwag w kwestii art. 173 \& 3 i 4 k.k.w., „Probacja” 2013, nr 1, s. 187.

11 K. Dąbkiewicz, Kodeks karny..., Komentarz do art. 173, Nb 13.

12 Ibidem.

13 K. Postulski, Decyzja kuratora..., s. 70-71.

14 R. Skręt, S. Stasiorowski, Sądowy kurator zawodowy w świetle nowelizacji Kodeksu karnego wykonawczego, „Probacja” 2012, nr 2, s. 151-152.

Nowa Kodyfikacja Prawa Karnego 54, 2019

(C) for this edition by CNS 
1. upomnienie jest, ,ingerencją w prawa i wolności obywatelskie zarówno z uwagi na jego istotę, jak też możliwe dalsze konsekwencje", dlatego musi mieć formę decyzji ${ }^{15}$;

2. istota upomnienia jest zgodna z definicją decyzji, gdyż ma ono charakter indywidualny (dotyczy określonego skazanego lub sprawcy) i konkretny (dotyczy ściśle określonych sytuacji), rozstrzyga sprawę w części lub całości i kończy sprawę (względnie) ${ }^{16}$.

W moim przekonaniu należy zgodzić się z drugim z zaprezentowanych poglądów, dlatego upomnienie należy uznać za decyzję, o której mowa w art. 7 k.k.w. Poza wskazaną argumentacją na uzasadnienie takiego stanowiska należy dodać, iż sądowy kurator zawodowy przed podjęciem decyzji o udzieleniu skazanemu (sprawcy) upomnienia lub przed złożeniem stosownego wniosku musi dokonać oceny merytorycznej zachowania skazanego (sprawcy) celem ustalenia, czy zostały spełnione przesłanki do zastosowania takiego trybu postępowania. Jedna $\mathrm{z}$ tych przesłanek ma charakter formalny - rażące naruszenie porządku prawnego (kurator stwierdza jej wystąpienie na podstawie prawomocnego wyroku sądu). Jednak nawet $\mathrm{w}$ tym wypadku niekiedy kwestią oceny pozostaje, czy dane zachowanie skazanego (sprawcy) jest rażącym naruszeniem porządku prawnego, czy też nie. Zwraca uwagę fakt, że nie chodzi tutaj o każde naruszenie porządku, ale jedynie o takie, które należy ocenić szczególnie negatywnie. W tym względzie dużo wątpliwości może pojawiać się przy ocenie popełnionego przez skazanego (sprawcę) wykroczenia, gdyż nie każde będzie można uznać za rażące naruszenie porządku prawnego ${ }^{17}$.

15 K. Postulski, Decyzja kuratora..., s. 77.

${ }^{16}$ K. Postulski, Kodeks karny wykonawczy. Komentarz, Warszawa 2017, Komentarz do art. 173, Nb 27; R. Skręt, S. Stasiorowski, op. cit., s. 151-152.

17 Postanowienie SA w Krakowie z 21 października 2015 roku, IIAKzw 965/15. W sentencji możemy przeczytać, iż ,zachowanie rażące, to jest zawierające znaczny ładunek jego pejoratywności, więc które jest nacechowane jaskrawością czy uporczywością oraz dużym nasileniem złej woli sprawcy. Przed podjęciem decyzji należy przeanalizować zachowanie skazanego polegające na dopuszczeniu się przestępstwa i ocenić, czy było to zachowanie 0 charakterze incydentalnym i jednorazowym, czy też było przejawem zdezaktualizowania się pozytywnej prognozy kryminologicznej”. Także Sąd Apelacyjny w Krakowie w postanowieniu z 29 maja 2015 roku, IIAKzw 408/15, uznał,

Nowa Kodyfikacja Prawa Karnego 54, 2019

(C) for this edition by CNS 
Pozostałe przesłanki przez sądowego kuratora zawodowego podlegają ocenie merytorycznej, gdyż do zastosowania przewidzianej w k.k.w. reakcji (złożenia wniosku lub udzielenie upomnienia) niezbędne jest najczęściej ustalenie, iż skazany (sprawca) uchyla się od ciążącej na nim powinności, na przykład od naprawienia szkody. Zatem nie będzie wystarczające stwierdzenie, że podsądny nie realizuje tego obowiązku, ale że nie robi tego w sposób intencjonalny, ze złej woli, mimo że ma taką możliwość (na przykład dysponuje odpowiednimi środkami finansowymi) ${ }^{18}$. W związku z tym udzielenie upomnienia nie jest, jak twierdzi Krzysztof Dąbkiewicz, czynnością materialno-techniczną (przyznającą, stwierdzającą lub uznającą odpowiednie uprawnienia bądź obowiązki), gdyż kurator dokonuje oceny merytorycznej zachowania skazanego (sprawcy) i na tej podstawie podejmuje decyzję o zastosowaniu w stosunku do niego odpowiedniej reakcji (złożenie wniosku lub udzielenie upomnienia).

Kolejną kwestią w bezpośredni sposób związaną z przedstawionymi rozważaniami jest możliwość złożenia przez skazanego lub sprawcę skargi na upomnienie. Takie uprawnienie ma on wówczas, gdy uznamy, że jest ono decyzją, o której mowa w art. 7 k.k.w. W tym miejscu należy zasygnalizować, iż K. Dąbkiewicz konsekwentnie kwestionuje możliwość zaskarżenia upomnienia przez skazanego (sprawcę). Podał on, że taka czynność nie może być dokonana, gdyż skazany (sprawca) nie ma gravamen (można skarżyć jedynie rozstrzygnięcia naruszające prawa lub szkodzące interesom skazanego lub sprawcy). Ponadto, jego zdaniem, upomnienie nie ma charakteru definitywnego, gdyż sądowy kurator zawodowy jest zobowiązany niezwłocznie przekazać je sądowi, co powoduje niejako „automatyczne” wszczęcie postępowania kontrolnego. Na tej podstawie wyciągnął on wniosek, że upomnienie nie ma charakteru definitywnego, a skarga przysługuje jedynie od decyzji, która ostatecznie i końcowo rozstrzyga sprawę konkretnego podsądnego ${ }^{19}$.

$\mathrm{Z}$ taką argumentacją trudno jednak się zgodzić. Przede wszystkim błędne jest twierdzenie, że skazany (sprawca) nie ma gravamen, gdyż w skardze

iż popełnienie wykroczenia jest naruszeniem porządku prawnego, jednak nie zawsze jest „rażące” tak, aby było powodem zarządzenia kary pozbawienia wolności.

18 Jako przykład takiego rozumienia można podać postanowienie SN z 4 kwietnia 2018 roku, VKK 66/18, LEX 2488988.

19 K. Dąbkiewicz, Kodeks karny..., Komentarz do art. 173, Nb 14.

Nowa Kodyfikacja Prawa Karnego 54, 2019

(C) for this edition by CNS 
może przecież dowodzić, iż sadowy kurator zawodowy w sposób nieprawidłowy zastosował przepisy prawa (materialnego, procesowego). Natomiast gdyby to prawo zostało użyte w sposób właściwy, to nie byłoby podstawy zarówno do udzielenia upomnienia, jak i do złożenia wniosku ${ }^{20}$.

W literaturze został też wyrażony pogląd, że upomnienie jest decyzją co do zasady podejmowaną na korzyść adresata ${ }^{21}$, gdyż jego alternatywą jest złożenie przez sądowego kuratora zawodowego odpowiedniego wniosku, co jest postrzegane jako bardziej dolegliwe. Oczywiście są wyjątki od tej reguły, gdyż z uwagi na konsekwencje jego udzielenia (względnie obligatoryjne podstawa do zarządzenia wykonania kary lub innej podobnie negatywnej decyzji sądu względem skazanego lub sprawcy) czasami zastosowanie upomnienia ma dla podsądnego bardziej dolegliwe skutki niż złożenie przez sądowego kuratora zawodowego odpowiedniego wniosku, albowiem w sposób poważny zwiększa ono prawdopodobieństwo uwzględnienia wniosku kuratora złożonego po wydaniu decyzji upomnienia. Takie twierdzenie jest tym bardziej uzasadnione, jeżeli weźmie się pod uwagę dane statystyczne, z których wynika, że w większości wypadków, jeżeli kurator nie zastosuje upomnienia, a od razu złoży wniosek, nie jest on przez sąd rozpatrywany pozytywnie ${ }^{22}$.

\section{Forma upomnienia, tryb jego udzielenie i zaskarżenia}

Forma upomnienia wynika z art. $173 \S 4$ k.k.w. oraz z art. $7 \S 3$ k.k.w. Zatem upomnienie musi mieć postać pisma. Jego niezbędnymi elementami są: dane personalne adresata; oznaczenie sprawy, w której upomnienie zostało udzielone; data wydania; treść upomnienia; jego uzasadnie-

${ }^{20}$ K. Postulski, Kodeks karny..., Komentarz do art. 173, Nb 30.

21 K. Dąbkiewicz, Zaskarżalność postanowień..., s. 107.

22 Jak wynika z danych statystycznych zawartych w druku MS-S10r, w 2014 roku (s. 12) na 18580 złożonych wniosków o zarządzenie kary pozbawienia wolności z powodu uchylania się od wykonywania nałożonych obowiązków lub środków karnych sąd uwzględnił tylko 8845, czyli 47\%. Natomiast z powodu rażącego naruszenia porządku prawnego (art. 75 § 2 k.k.) na 26139 wniosków, uwzględniono 11 108, czyli 42\%. Dosyć zbliżone proporcje występowały w 2016 roku: uchylanie się od wykonywania obowiązków, środków karnych, środków kompensacyjnych lub przepadku — złożono 18 238, uwzględniono zaś 9165 (50\%); rażące naruszanie porządku prawnego — złożono 18080 , uwzględniono zaś 8267 (45,7\%).

Nowa Kodyfikacja Prawa Karnego 54, 2019

(C) for this edition by CNS 
nie; pouczenie o możliwości złożenia skargi oraz dane i podpis sądowego kuratora zawodowego, który upomnienia udzielił (art. 119 k.p.k. w zW. $\mathrm{z}$ art. $1 \S 2$ k.k.w. $)^{23}$. Ponieważ skazany może zaskarżyć upomnienie z powodu jego niezgodności z prawem, dlatego powinno ono zawierać uzasadnienie prawne i faktyczne wskazujące na powody jego wydania. Z uwagi na treść art. $173 \S 3$ k.k.w. sądowy kurator zawodowy może skazanemu lub sprawcy udzielić upomnienia, jeżeli za odstąpieniem od złożenia odpowiedniego wniosku przemawiają „rodzaj i stopień naruszenia uzasadniające przekonanie, że pomimo odstąpienia od złożenia wniosku, cele środka związanego z poddaniem skazanego lub sprawcy próbie zostaną osiągnięte". W związku z tym należy zgodzić się z Kazimierzem Postulskim, że uzasadnienie upomnienia powinno zawierać także argumentację, „która przemawia za odstąpieniem od wystąpienia do sądu ze stosownym wnioskiem" 24 .

W doktrynie pojawił się pogląd, że art. $173 \S 3$ k.k.w. jest wewnętrznie sprzeczny, gdyż jeżeli istnieją okoliczności uzasadniające podjęcie czynności przewidzianych $\mathrm{w}$ art. $68 \S 2$ k.k., art. $75 \S 2$ k.k., art. 156 $\S 1$ k.k.w. lub art. $160 \S 3$ k.k.w., to nie można tego logicznie pogodzić z koniecznością ustalenia, że rodzaj i stopień naruszenia uzasadniają, że mimo odstąpienia od złożenia wniosku cele próby zostaną osiągnięte ${ }^{25}$. Czyli jeżeli skazany dopuścił się na przykład rażącego naruszenia porządku prawnego, to jak na tej podstawie można wyciągnąć wniosek, że cele probacji zostaną spełnione. Bez wątpienia uwaga ta jest trafna, gdyż trudno na negatywnym zachowaniu jakiejś osoby budować przekonanie, że w przyszłości będzie się ona zachowywała pozytywnie. Z uwagi na to art. $173 \S 3$ k.k.w. powinien, poza badaniem okoliczności negatywnego zachowania, określać też konieczność dokonania przez sądowego kuratora zawodowego oceny dotychczasowej postawy skazanego (sprawcy).

23 Podobnie jak w przypadku wniosków K. Stasiak, Wnioski składane przez kuratora dla dorostych, [w:] Zarys metodyki pracy kuratora sądowego, red. K. Stasiak, Warszawa 2018, s. 592-594.

24 K. Postulski, Kodeks karny..., Komentarz do art. 173, Nb 29.

25 S. Lelental, Kodeks karny wykonawczy. Komentarz, Warszawa 2012, Komentarz do art. 173, $\mathrm{Nb} 15$. To stanowisko zostało poparte przez Leszka Osińskiego, Komentarz do art. 173, Nb 20, [w:] Kodeks karny wykonawczy. Komentarz, red. J. Lachowski, Warszawa 2018.

Nowa Kodyfikacja Prawa Karnego 54, 2019

(C) for this edition by CNS 
Po udzieleniu upomnienia zgodnie z art. $7 \S 3$ k.k.w. jego adresat w terminie 7 dni od doręczenia lub ogłoszenia decyzji może złożyć do sądu skargę z powodu jego niezgodności z prawem. W doktrynie przyjmuje się, że termin „niezgodność z prawem” należy interpretować szeroko, w związku z tym obejmuje on nie tylko naruszenie przepisów k.k.w., lecz także innych ustaw będących podstawą wydania decyzji, ale również naruszenie ratyfikowanych umów międzynarodowych, bezpośrednio stosowanych norm Konstytucji RP, przepisów rozporządzeń oraz innych aktów zawierających normy prawne ${ }^{26}$. Termin ten obejmuje normy prawa zarówno materialnego, jak i procesowego, czyli określających procedurę wydania decyzji. Przez naruszenie prawa materialnego należy rozumieć dokonanie oceny prawnej konkretnego zachowania skazanego (sprawcy), na przykład czy zachowanie to należy kwalifikować jako uchylanie się od dozoru.

Jak wynika z art. 7 § 3 k.k.w., termin na złożenie przez skazanego lub sprawcę skargi na decyzję jest liczony od momentu jej doręczenia bądź ogłoszenia. W wypadku upomnienia istnieje wymóg udzielenia go na piśmie (art. 173 § 4 k.k.w.), dlatego termin na wniesienie skargi należy liczyć od momentu otrzymania przez adresata tego rodzaju pisma (lex specialis derogat legi generali). Naturalnie nie ma przeciwwskazań do tego, aby najpierw z treścią upomnienia zapoznać adresata ustnie, zwłaszcza gdy jest ono udzielane w trakcie osobistego kontaktu kuratora ze skazanym lub sprawcą. Takie omówienie upomnienia może mieć istotny walor profilaktyczny, gdyż pozwala skazanemu (sprawcy) lepiej zrozumieć znaczenie tej decyzji i jej konsekwencje dla jego sytuacji prawnej.

Z uwagi na wskazaną rolę upomnienia, która polega na zdyscyplinowaniu skazanego (sprawcy) oraz stworzeniu mu możliwości poprawy swojego zachowania, konieczne jest, aby adresat tego rodzaju decyzję otrzymał. Przekazanie upomnienia może nastąpić w czasie osobistego kontaktu sądowego kuratora zawodowego ze skazanym lub sprawcą bądź przez przesłanie go adresatowi (za pośrednictwem poczty). Możliwe jest

26 S. Lelental, Kodeks karny..., 2010, s. 99; K. Postulski, Decyzja kuratora..., s. 88-89; T. Kalisz, op. cit., s. 154.

Nowa Kodyfikacja Prawa Karnego 54, 2019

(C) for this edition by CNS 
też doręczenie pisma za pośrednictwem telefaksu lub poczty elektronicznej (art. $132 \S 3$ k.p.k. ${ }^{27}$ w związku z art. 1 § 2 k.k.w.).

Jeżeli upomnienie zostało przesłane pocztą, możliwe jest, że skazany (sprawca) nie odbierze go i korespondencja wróci do nadawcy. Ponieważ, jak słusznie zauważył Kazimierz Postulski, każda decyzja sądowego kuratora zawodowego $\mathrm{w}$ rozumieniu art. 7 k.k.w. jest wykonalna $\mathrm{z}$ chwilą wydania $^{28}$ (co wynika z treści art. $7 \S 4$ k.k.w. — sąd powołany do rozpoznania skargi może wstrzymać wykonanie zaskarżonej decyzji), dlatego należy uznać, że w takim wypadku upomnienie jest wykonalne, jednak dla skazanego (sprawcy) nie zaczyna biec termin do złożenia skargi do właściwego sądu na jej niezgodność z prawem (brak podstawy prawnej do zastosowania domniemania doręczenia, o którym mowa w art. $133 \S 2$ k.p.k.). Trzeba jednak podkreślić, że udzielenie przez sądowego kuratora zawodowego upomnienia w takim trybie stoi w sprzeczności z celem tej instytucji. Jeżeli bowiem skazany (sprawca) nie wie o tym, że upomnienie zostało mu udzielone, to trudno oczekiwać, iż jego treść w jakikolwiek sposób wpłynie na jego zachowanie. $Z$ tego powodu należy przyjąć, że sądowy kurator zawodowy powinien dokonać wszelkich możliwych starań, aby upomnienie trafiło do adresata. $\mathrm{W}$ tej sytuacji problematyczne jest na przykład udzielenie skazanemu upomnienia z powodu uchylania się od dozoru, gdy nie jest znane jego miejsce pobytu i z bardzo dużym prawdopodobieństwem można przypuszczać, że upomnienie nie będzie skutecznie doręczone. W moim przekonaniu w takim wypadku sądowy kurator zawodowy nie powinien dozorowanemu udzielać upomnienia, gdyż z uwagi na brak kontaktu z nim nie można sformułować hipotezy, że ,cele środka związanego z poddaniem skazanego lub sprawcy próbie zostaną osiągnięte" (art. 173 § 3 k.k.w.). Wówczas powinien być złożony stosowny do okoliczności sprawy wniosek.

Skazany (sprawca) skargę na upomnienie składa (jeżeli podejmie taką decyzję) do właściwego sądu za pośrednictwem sądowego kuratora zawodowego, który udzielił upomnienia. Kurator odmawia jej przyjęcia, jeżeli wystąpią okoliczności, o których mowa w art. 429 § 1 k.p.k. (zo-

${ }^{27}$ Ustawa z dnia 6 czerwca 1997 roku - Kodeks postępowania karnego (tekst jedn. Dz.U. z 2016 r. poz. 1749 ze zm.).

${ }^{28}$ K. Postulski, Decyzja kuratora..., s. 90.

Nowa Kodyfikacja Prawa Karnego 54, 2019

(C) for this edition by CNS 
stała ona złożona po terminie lub przez osobę nieuprawnioną) $)^{29}$. Osobą uprawnioną do wniesienia skargi jest tylko jej adresat lub jego obrońca, jeżeli został ustanowiony. Gdy skazany (sprawca) jest nieletni lub ubezwłasnowolniony, może ją wnieść również jego przedstawiciel ustawowy lub osoba, pod której pieczą adresat upomnienia pozostaje (art. 76 k.p.k. w zw. z art. $1 \S 2$ k.k.w.). Natomiast skargi nie może wnieść przedstawiciel skazanego (sprawcy), o którym mowa w art. 42 k.k.w. czy też prokurator $^{30}$.

Odmowa przyjęcia skargi następuje w formie decyzji, na którą przysługuje skarga do właściwego sądu. W tym wypadku nie stosujemy art. 429 § 2 k.p.k. (że odmowa przyjęcia skargi następuje w formie zarządzenia), gdyż przepis ten ma zastosowanie do sądu ${ }^{31}$.

Sądowy kurator zawodowy po otrzymaniu skargi na upomnienie jest zobowiązany przeanalizować zawarte w niej argumenty i na tej podstawie może podjąć decyzję o jej uwzględnieniu. Jeżeli tego nie zrobi, bezzwłocznie przekazuje ją wraz z aktami sprawy do właściwego sądu. Sąd na podstawie art. $7 \S 4$ k.k.w. może wstrzymać wykonanie zaskarżonej decyzji, jednak w wypadku upomnienia, którego skutki uwidaczniają się dopiero w momencie rozpatrywania przez sąd wniosku kuratora, takie wstrzymanie na ogół będzie bezcelowe. Sąd po rozpoznaniu skargi orzeka o utrzymaniu decyzji w mocy, jej uchyleniu albo zmianie. Na wydane $\mathrm{w}$ tej sprawie postanowienie sądu zażalenie nie przysługuje.

W tym miejscu warto się też zastanowić nad problemem, czy sądowy kurator zawodowy, udzielając skazanemu (sprawcy) upomnienia, decyzję tę może z własnej inicjatywy zmienić (uchylić). Kodeks karny wykonawczy na to pytanie nie daje nam odpowiedzi wprost, ale ponieważ kurator na podstawie art. $7 \S 3$ k.k.w. może przychylić się do skargi skazanego lub sprawcy (zatem może je zmienić lub uchylić), to wydaje się, że tym bardziej taką modyfikację upomnienia (lub jego uchylenie) może podjąć z własnej inicjatywy (argumentum a maiori ad minus). Jest

29 Ibidem, s. 89.

30 J. Lachowski, T. Oczkowski, Skarga skazanego w postępowaniu wykonawczym (art. 7 k.k.w.), „Przegląd Więziennictwa Polskiego” 2008, nr 61, s. 10-11; K. Postulski, Status skazanego w postępowaniu przed sądem, „Państwo i Prawo” 2010, nr 1-2, s. 222.

31 K. Postulski, Decyzja kuratora..., s. 89-90; J. Lachowski, T. Oczkowski, op . cit., s. $12-13$.

Nowa Kodyfikacja Prawa Karnego 54, 2019

(C) for this edition by CNS 
to problem o tyle istotny, że kurator po udzieleniu upomnienia może dojść do przekonania, że dokonał tego na podstawie błędnych przesłanek. W takiej sytuacji uchylenie decyzji przez sądowego kuratora zawodowego, jeżeli dostrzeże popełniony błąd, jest logiczne i celowe. Natomiast więcej wątpliwości może pojawiać się wówczas, gdy sądowy kurator zawodowy postanowił uchylić upomnienie i złożyć do sądu odpowiedni wniosek. Wydaje się, że taka sytuacja też jest możliwa, jednak z pewnością z punktu widzenia metodyki pracy kuratora sądowego do prawidłowych nie należy ${ }^{32}$.

Z treści art. $173 \S 5$ k.k.w. wynika, że sądowy kurator zawodowy skazanemu (sprawcy) upomnienia w jednej sprawie może udzielić tylko raz. Przy czym nie ma znaczenia, z jakiego lub jakich powodów zostało ono udzielone. Jeżeli po jego zastosowaniu wystąpią okoliczności, o których mowa w art. $173 \S 3$ k.k.w. (fakultatywna podstawa do zarządzenia wykonania kary, odwołania warunkowego zwolnienia, podjęcia warunkowo umorzonego postępowania karnego lub odwołania przerwy bądź odroczenia kary), to jest on zobowiązany złożyć do sądu odpowiedni wniosek $^{33}$. Zatem może wystąpić sytuacja, gdy skazany otrzymał upomnienie z powodu uchylania się od dozoru (na przykład przy zawieszeniu kary pozbawienia wolności). Po jego udzieleniu zaczął stosować się do wymagań związanych z dozorem, jednak w tym czasie dopuścił się rażącego naruszenia porządku prawnego. Mimo że ta przesłanka różni się od tej, z powodu której upomnienie zostało udzielone, to obie mieszczą się w treści art. $75 \S 2$ k.k., dlatego w tym wypadku sądowy kurator zawodowy jest zobowiązany złożyć wniosek o zarządzenie wykonania kary.

Kolejną kwestią, która wymaga omówienia, jest rola sądu w procedurze stosowania przez sądowego kuratora zawodowego upomnienia. Zgodnie z art. $173 \S 4$ k.k.w. sądowy kurator zawodowy, udzielając skazanemu (sprawcy) upomnienia, jest zobowiązany jego odpis niezwłocznie przekazać sądowi.

32 Szerzej Zarys metodyki pracy kuratora sądowego, red. K. Stasiak, Warszawa 2018

${ }^{33}$ K. Postulski, Glosa do postanowienia s. apel. z dnia 5 listopada 2015 r., II AKzw 635/15, teza 5, LEX 2016, nr 302782/5; K. Postulski, Kodeks karny..., Komentarz do art. $173, \mathrm{Nb} 24$.

Nowa Kodyfikacja Prawa Karnego 54, 2019

(C) for this edition by CNS 
Zdaniem Krzysztofa Dąbkowskiego przekazanie sądowi odpisu upomnienia skutkuje ,automatycznym” wszczęciem przez ten sąd postępowania kontrolnego ${ }^{34}$. Co, jak sądzi, oznacza, że nie ma ono charakteru definitywnego, gdyż jego trwałość zależy od wyniku tego postępowania. Natomiast zdaniem Kazimierza Postulskiego przekazanie sądowi odpisu upomnienia umożliwia temu organowi weryfikację tej decyzji, ale jedynie w zakresie zastosowania prawidłowej podstawy prawnej do jej wydania. Brakuje zaś podstawy prawnej, aby sąd badał, czy kurator dokonał prawidłowej oceny okoliczności faktycznych, które zostały przyjęte za podstawę udzielenia upomnienia. Poza tym z treści przepisów dotyczących upomnienia nie wynika, aby sąd miał obowiązek ustosunkowania się w jakiejkolwiek formie do upomnienia ${ }^{35}$.

Bez wątpienia samo przekazanie odpisu upomnienia sądowi nie wszczyna postępowania kontrolnego, ale co najwyżej może być powodem zainicjowania w przyszłości tego postępowania. Trzeba zwrócić uwagę, że sąd otrzymuje jedynie odpis upomnienia, a informacje stanowiące przyczynę jego wydania znajdują się w teczce sprawy, która nadal pozostaje w dyspozycji kuratora. Jedynie w wypadku złożenia przez skazanego (sprawcę) skargi na decyzję kurator jest zobowiązany przesłać ją sądowi wraz z aktami sprawy (jeżeli nie przychyli się do skargi). Z uwagi na to trzeba zgodzić się z Kazimierzem Postulskim, że sąd na podstawie przesłanego odpisu upomnienia może zbadać jedynie to, czy sądowy kurator zawodowy w sposób prawidłowy zastosował przepisy. Natomiast nie ma możliwości dokonania weryfikacji, czy istniały merytoryczne przesłanki do podjęcia przez niego takiej decyzji.

Z kodeksu karnego wykonawczego nie wynika, aby sąd był uprawniony do uchylenia lub zmiany z urzędu udzielonego przez sądowego kuratora zawodowego upomnienia. Takie kompetencje (uchylenie decyzji) zostały przyznane jedynie sądowi penitencjarnemu, jeżeli decyzja dotyczy osoby pozbawionej wolności (art. $34 \S 1$ k.k.w.). Z tego powodu, gdy sąd stwierdzi, że upomnienie zostało udzielone z naruszeniem obowiązujących w tym zakresie przepisów, może sądowemu kuratorowi zawodowemu zwrócić na to uwagę na przykład pisemnie, przedstawia-

34 K. Dąbkiewicz, Kodeks karny..., Komentarz do art. 173, Nb 14.

35 K. Postulski, Kodeks karny..., Komentarz do art. 173, Nb 22 i 30.

Nowa Kodyfikacja Prawa Karnego 54, 2019

(C) for this edition by CNS 
jąc dostrzeżony problem ${ }^{36}$. Wówczas sądowy kurator zawodowy, który udzielił upomnienia, powinien je zmienić lub uchylić. Warto też zasygnalizować, że w k.k.w. przewidziano nadzór sądu lub sędziego nad wykonywaniem jedynie niektórych orzeczeń:

1. art. 32 - nadzór nad legalnością i prawidłowością wykonywania kary pozbawienia wolności, zastępczej kary pozbawienia wolności, kary aresztu wojskowego, kary aresztu lub zastępczej kary aresztu, kary porządkowej, tymczasowego aresztowania, zatrzymania, środka przymusu skutkującego pozbawieniem wolności oraz środka zabezpieczającego związanego z umieszczeniem w zakładzie psychiatrycznym;

2. art. $43 \mathrm{~d}$ - nadzór nad wykonywaniem kar z zastosowaniem dozoru elektronicznego;

3. art. $55 \S 1$ - nadzór nad wykonywaniem kary ograniczenia wolności;

4. art. 169a - nadzór nad wykonywaniem dozoru.

W tym katalogu brakuje na przykład prowadzonych przez sądowych kuratorów zawodowych spraw, w których wobec skazanego (sprawcy) został ustanowiony okres próby, natomiast nie został wobec nich zastosowany dozór (czyli tak zwane kontrole okresu próby). Z tego powodu w tym wypadku w sytuacji udzielenia skazanemu (sprawcy) upomnienia kontrola tej decyzji w wyżej określonym trybie wydaje się co najmniej problematyczna.

Inną, najczęściej stosowaną formą wpływania przez sąd na sytuację prawną skazanego (sprawcy), któremu sądowy kurator zawodowy udzielił upomnienia, jest wszczęcie postępowania incydentalnego na przykład w przedmiocie zarządzenia kary pozbawienia wolności. Nie ulega wątpliwości, że udzielenie skazanemu (sprawcy) upomnienia nie ogranicza sądu w podjęciu decyzji, aby z urzędu wszcząć postępowanie incydentalne $^{37}$. Natomiast interesujące będzie oddziaływanie wyniku tego postępowania na wcześniej zastosowane wobec uczestnika postępowania upomnienie. Jeżeli sąd postanowił, w zależności od rodzaju sprawy (ale opierając się na tych samych okolicznościach, na podstawie których zostało udzielone upomnienie), zarządzić wykonanie kary, odwołać warunkowe zwolnienie, podjąć warunkowo umorzone postępowanie karne

${ }^{36}$ L. Osiński, Komentarz do art. 173, Nb 22, [w:] Kodeks karny...

${ }^{37}$ K. Postulski, Kodeks karny..., Komentarz do art. 173, Nb 27; R. Skręt, S. Stasiorowski, op. cit., s. 152.

Nowa Kodyfikacja Prawa Karnego 54, 2019

(C) for this edition by CNS 
lub odwołać przerwę lub odroczenie kary, to niejako w sposób dorozumiany dochodzi do uchylenia decyzji o udzieleniu skazanemu (sprawcy) upomnienia. Sąd, wydając niekorzystne dla uczestnika postępowania postanowienie, dokonuje innej niż sądowy kurator zawodowy oceny okoliczności sprawy i w ten sposób poniekąd stwierdza, że udzielenie upomnienia było niewystarczające. Natomiast jeżeli sąd takiego niekorzystnego dla skazanego (sprawcy) postanowienia nie wyda, należałoby uznać, że upomnienie nadal obowiązuje, gdyż pierwotne orzeczenie jest wykonywane w dotychczasowym trybie. Może się zdarzyć, że sąd w wyniku postępowania nałoży na skazanego (sprawcę) nowe obowiązki (rozszerzy dotychczasowe lub zmieni je), ale również w tym wypadku brakuje podstaw prawnych do uznania, aby miało to jakikolwiek wpływ na obowiązywanie upomnienia.

Reasumując, należy uznać, że ciążący na sądowym kuratorze zawodowym obowiązek niezwłocznego przekazania odpisu udzielonego skazanemu (sprawcy) upomnienia ma głównie cel informacyjny i jest między innymi realizacją obowiązku wynikającego z art. 172 § 2 k.k.w. (informowanie sądu o popełnieniu przez skazanego przestępstwa lub o innym rażącym naruszeniu przez niego porządku prawnego). Natomiast cel kontrolny jest przez sąd pośrednio realizowany tylko poprzez weryfikację adekwatności reakcji podjętej przez kuratora sądowego do stopnia naruszeń obowiązków, które na skazanym (sprawcy) ciążą. Ma to miejsce w wyniku wszczętego przez sąd postępowania incydentalnego.

\section{Wybrane uwarunkowania stosowania upomnień przez kuratorów sądowych}

Do omawianej instytucji prawnej w kilku miejscach odniesiono się też w rozporządzeniu Ministra Sprawiedliwości w sprawie sposobu i trybu wykonywania czynności przez kuratorów sądowych (dalej: rozporządzenie) ${ }^{38}$. Zgodnie z $§ 6$ ust. 2 tego aktu prawnego, jeżeli skazany lub sprawca bez należytego uzasadnienia dwukrotnie nie stawi się na wezwanie kuratora, kurator zawodowy składa do sądu wniosek o podjęcie

38 Rozporządzenie Ministra Sprawiedliwości z dnia 13 czerwca 2016 roku w sprawie sposobu i trybu wykonywania czynności przez kuratorów sądowych w sprawach karnych wykonawczych (Dz.U. z 2016 r. poz. 969).

Nowa Kodyfikacja Prawa Karnego 54, 2019

(C) for this edition by CNS 
postępowania warunkowo umorzonego, o zarządzenie wykonania kary, o odwołanie warunkowego zwolnienia albo udziela skazanemu (sprawcy) „pisemnego” upomnienia. Norma ta dotyczy wyłącznie dozorów, gdyż została umieszczona w rozdziale 2 zatytułowanym Sprawowanie dozoru. Treść tego przepisu wzbudza wątpliwości, w szczególności jego zgodność z k.k. (art. 75 § 2, art. 68 § 2) i k.k.w. (160 § 3, art. 173 § 3). Żaden z tych kodeksów nie zdefiniował pojęcia ,uchylanie się od dozoru”. Zostało ono dookreślone przez judykaturę, ale mimo to kryteria oceny, czy dane zachowanie skazanego (sprawcy) należy uznać za uchylanie się od dozoru, pozostają nadal nieostre. Natomiast zgodnie z rozporządzeniem kurator zawodowy jest zobowiązany uznać, że dwukrotne niestawiennictwo dozorowanego na wezwanie (bez należytego usprawiedliwienia) jest uchylaniem się od dozoru, gdyż jedynie w taki sposób może uzasadnić swój wniosek lub decyzję o udzieleniu upomnienia. Zatem poniekąd rozporządzenie definiuje treść ustawy, co nie jest sytuacją prawidłową.

Jeszcze więcej wątpliwości powoduje $\S 6$ ust. 3 rozporządzenia, zgodnie z którym kurator zawodowy składa do sądu jeden z wniosków (odpowiedni do sytuacji), o których jest mowa wyżej, albo udziela skazanemu (sprawcy) ,pisemnego" upomnienia także wówczas, gdy kurator społeczny zawiadomi go, że skazany uchyla się od nawiązania pierwszego kontaktu. Z treści tego przepisu wynika, że to kurator społeczny dokonuje oceny, czy dane zachowanie dozorowanego zakwalifikować jako uchylanie się od nawiązania pierwszego kontaktu, czy też nie. Jeżeli dojdzie do przekonania, że uchylanie występuje i zawiadomi o tym kuratora zawodowego, to ten jest zobowiązany złożyć odpowiedni wniosek lub udzielić skazanemu (sprawcy) upomnienia. Wypada przypomnieć, że zgodnie z art. $75 \S 2$ k.k., art. 68 § 2 k.k., art. i $160 \S 3$ k.k.w. sąd może orzec, w sposób w nich przewidziany, jeżeli skazany (sprawca) między innymi uchyla się od dozoru. Co prawda uchylanie się od nawiązania pierwszego kontaktu z kuratorem społecznym może też być uznane za uchylanie się od dozoru, ale nie zawsze taka ocena dokonana przez kuratora społecznego będzie uprawniona. Tym bardziej że na ogół ma on w tym zakresie zdecydowanie mniejsze umiejętności niż kurator zawodowy. Poza tym z przytoczonej treści rozporządzenia wynika, że ponownie dokonano w nim wykładni pojęcia „uchylanie się od dozoru”. Tym 
razem uznano za nie uchylanie się przez skazanego (sprawcę) od nawiązania pierwszego kontaktu z kuratorem społecznym.

$Z$ treści $\S 6$ ust. 3 rozporządzenia wynika też, że to kurator społeczny dokonuje oceny zachowania dozorowanego w zakresie uchylania się od nawiązania pierwszego kontaktu, natomiast rola kuratora zawodowego została sprowadzona jedynie do wyboru formy reakcji (wniosek lub upomnienie). Taka konstrukcja wydaje się sprzeczna z art. 173 § 2 i 3 k.k.w., z których jednoznacznie wynika, że to kurator zawodowy, a nie kurator społeczny dokonuje oceny, czy zaistniały przesłanki do zastosowania przewidzianej tam reakcji.

Zgodnie z § 34 ust. 1 i 3 rozporządzenia, jeżeli sądowy kurator zawodowy kontroluje wykonanie przez skazanego (sprawcę) obowiązków z określonym terminem ich wykonania, to po jego upływie, gdy zobowiązany do ich wykonania od nich się uchyla, kurator zawodowy składa do sądu stosowny wniosek albo udziela „pisemnego” upomnienia. Gdy jednak termin na wykonanie obowiązku minął, a jego niewykonanie w wyznaczonym terminie nie wynikało z winy skazanego (sprawcy), to kurator pisemnie informuje o tym sąd wraz z podaniem uzasadnienia, dlaczego odstąpił od złożenia stosownego wniosku lub udzielenia skazanemu (sprawcy) upomnienia.

Natomiast gdy skazany lub sprawca ma do wykonania obowiązek o charakterze stałym, na przykład obowiązek powstrzymania się od nadużywania alkoholu, i kurator ustali, że uchyla się on od jego wykonania, to zgodnie z $§ 35$ ust. 3 rozporządzenia niezwłocznie składa do sądu stosowny wniosek lub udziela mu pisemnego upomnienia ${ }^{39}$.

Skutkiem udzielenia skazanemu (sprawcy) przez sądowego kuratora zawodowego upomnienia jest konieczność zarządzenia przez sąd kary (art. 75 § 2a k.k.), podjęcia warunkowo umorzonego postępowania karnego (art. 68 § 2a k.k.), odwołania warunkowego zwolnienia (art. $160 \S 4$ k.k.w.), odwołania przerwy lub odroczenia wykonania kary (art. $156 \S 3$ k.k.w.), chyba że przemawiają przeciwko temu szczególne względy. Przepisy te pozwalają sądowi uwzględnić sytuację skazanego (sprawcy), która czasami bywa bardzo skomplikowana, jak też jego motywacje do

39 Używany w rozporządzeniu przymiotnik ,pisemne” dla określenia upomnienia jest zbędny, gdyż taka forma upomnienia wynika z art. 173 § 4 k.k.w., dlatego nie ma potrzeby ciągłego powtarzania, iż upomnienie musi mieć formę pisemną.

Nowa Kodyfikacja Prawa Karnego 54, 2019

(C) for this edition by CNS 
zmiany zachowania. Przepisy te stanowią również swoisty „wentyl bezpieczeństwa" w wypadku, gdy upomnienie zostało adresatowi udzielone z naruszeniem prawa, a skazany (sprawca) na decyzję kuratora nie złożył skargi ${ }^{40}$. W konsekwencji upomnienie, mimo że jest błędne, pozostaje w obiegu prawnym i wywiera skutki w prawie przewidziane.

Brakuje też podstaw do przyjęcia, że sąd ma uprawnienie do nakazania sądowemu kuratorowi zawodowemu, aby ten udzielił skazanemu upomnienia lub uzależnienia decyzji o zarządzeniu kary (na podstawie art. $75 \S 2$ k.k.), podjęciu warunkowo umorzonego postępowania karnego (na podstawie art. 68 § 2 k.k.), odwołania warunkowego zwolnienia (na podstawie art. $160 \S 3$ k.k.w.), odwołania przerwy lub odroczenia kary (na podstawie art. $156 \S 1$ lub 2 k.k.w.) od wcześniejszego udzielenia skazanemu (sprawcy) upomnienia ${ }^{41}$.

$\mathrm{Na}$ podstawie analizy przepisów należy wyciągnąć wniosek, że dopuszczalna jest sytuacja, gdy sądowy kurator zawodowy po zaistnieniu okoliczności, o których mowa w art. 173 § 3 k.k.w., złoży do sądu stosowny wniosek. W sytuacji gdy nie zostanie on uwzględniony i ponownie wystąpią okoliczności, o których mowa w tym artykule, udzieli skazanemu (sprawcy) upomnienia. Warunkiem jest jednak ustalenie, że „rodzaj i stopień naruszenia uzasadniają przekonanie, iż pomimo odstąpienia od złożenia wniosku, cele środka związanego z poddaniem skazanego lub sprawcy próbie zostaną osiągnięte".

$\mathrm{Na}$ koniec wypada zwrócić uwagę, że uprawnienie sądowego kuratora zawodowego do udzielenia skazanemu upomnienia $\mathrm{w}$ sytuacji, o której mowa w art. 156 § 1 i 2 k.k.w. (odroczenie i przerwa w karze pozbawienia wolności), jest iluzoryczne, gdyż zgodnie z art. $151 \S 5$ i art. $153 \S 2$ k.k.w., sąd do wykonania takiego orzeczenia, jeżeli na skazanego nałożono obowiązki, stosuje art. 14 k.k.w., czyli okresowo zarządza przeprowadzenie przez kuratora sądowego wywiadu środowiskowego. Jeżeli kurator, przeprowadzając wywiad, stwierdza, że skazany nie realizuje nałożonych na niego obowiązków lub wykorzystuje przerwę lub odroczenie $\mathrm{w}$ sposób niezgodny $\mathrm{z}$ jej przeznaczeniem, to $\mathrm{w}$ spra-

40 L. Osiński, Komentarz do art. 173, Nb 22, [w:] Kodeks karny...

41 Postanowienie SA w Białymstoku z dnia 24 listopada 2014 roku, IIAKzw 2188/14, KZS 2015/2/81; K. Postulski, Glosa do postanowienia s. apel. z dnia 5 listopada 2015 r., IIAKzw 635/15, teza nr 3, LEX 2016, nr 302782/3.

Nowa Kodyfikacja Prawa Karnego 54, 2019

(C) for this edition by CNS 
wozdaniu z tego wywiadu informuje o tym sąd. Natomiast na ogół nie zdarza się, aby kurator w takiej sytuacji udzielił skazanemu upomnienia. Świadczy o tym między innymi fakt, że nawet w druku statystycznym dotyczącym wykonywanych przez kuratorów zadan (MS-S40r) w tabeli poświęconej upomnieniom nie przewidziano takiej kategorii jak upomnienia udzielone w związku z wykonywaną przerwą lub odroczeniem kary pozbawienia wolności.

\section{Podsumowanie}

Reasumując, należy stwierdzić, że instytucja upomnienia, o którym mowa $\mathrm{w}$ art. $173 \S 3$ k.k.w., jest interesującym narzędziem wpływania przez sądowego kuratora zawodowego na zachowanie skazanego lub sprawcy, a prawidłowo zastosowane z pewnością może zwiększyć prawdopodobieństwo pomyślnego zakończenia okresu próby. Na podstawie analizy przepisów, orzecznictwa i literatury przedmiotu należy uznać, że:

1. upomnienie jest decyzją, o której mowa w art. 7 k.k.w.;

2. upomnienie musi mieć postać pisma, które powinno zawierać dane personalne adresata; oznaczenie sprawy, w której upomnienie zostało udzielone; datę wydania; treść upomnienia; jego uzasadnienie (faktyczne i prawne oraz argumenty, dlaczego kurator odstąpił od złożenia odpowiedniego wniosku i udzielił upomnienia); pouczenie o możliwości złożenia skargi oraz dane i podpis sądowego kuratora zawodowego, który upomnienia udzielił;

3. kurator po udzieleniu skazanemu (sprawcy) upomnienia może dokonać jego zmiany lub je uchylić na skutek złożonej skargi na nie, ale też może tego dokonać z własnej inicjatywy;

4. upomnienie nie powinno być udzielane, jeżeli z okoliczności sprawy wynika, że skazany (sprawca) go nie odbierze i tym samym nie będzie znał jego treści. Podstawowym celem tej instytucji jest zdyscyplinowanie podsądnego do prawidłowego wypełniania warunków okresu próby. Gdy zastosujemy upomnienie, wiedząc o tym, że z bardzo dużym prawdopodobieństwem nie dojdzie do adresata, to ten cel nie może być osiągnięty;

5. przekazanie przez kuratora sądowego odpisu upomnienia sądowi nie oznacza, że następuje wszczęcie procedury kontrolnej. Fakt udzielenia upomnienia nie ogranicza sądu i może on na podstawie tych saNowa Kodyfikacja Prawa Karnego 54, 2019

(C) for this edition by CNS 
mych okoliczności wszcząć postępowanie incydentalne i orzec zależnie od okoliczności w sposób przewidziany w art. $160 \S 3$ k.k.w., art. 68 $\S 2$ k.k., art. $156 \S 1$ lub 2 k.k.w. oraz art. 75 § 2 k.k.;

6. upomnienie, nawet wadliwie udzielone, jeżeli nie zostało przez sąd uchylone na skutek skargi złożonej przez uprawnioną osobę, jest ważne i wywiera skutki prawne;

7. sądowy kurator zawodowy tylko raz może udzielić upomnienia skazanemu (sprawcy) w jednej sprawie;

8. jeżeli zachodzą przesłanki, o których mowa w art. $173 \S 3$ k.k.w., możliwe jest złożenie przez kuratora odpowiedniego wniosku, a w wypadku nieuwzględnienia go przez sąd i ponownego wystąpienia wymienionych przesłanek udzielenie skazanemu (sprawcy) upomnienia;

9. wybór reakcji w postaci złożenia odpowiedniego wniosku lub udzielenia upomnienia na stwierdzone niewłaściwe zachowanie skazanego (sprawcy) należy do sądowego kuratora zawodowego. Sąd nie może uzależniać złożenia przez kuratora wniosku od wcześniejszego udzielenia przez niego skazanemu (sprawcy) upomnienia;

10. przyznanie kuratorowi sądowemu uprawnienia do udzielenia skazanemu upomnienia w wypadku, gdy sąd udzielił mu odroczenia lub przerwy w karze pozbawienia wolności (art. $156 \S 1$ i 2 k.k.w.), jest zbędne, gdyż kuratorzy tego rodzaju spraw nie prowadzą i dlatego takich upomnień nie udzielają.

Na koniec należy dodać, że regulacje prawne określające zasady stosowania omawianej instytucji nie zawsze są precyzyjne, dlatego wymagają pewnej modyfikacji. W szczególności dotyczy to przesłanek, które kurator zawodowy powinien brać pod uwagę przed ewentualnym podjęciem decyzji o udzieleniu skazanemu (sprawcy) upomnienia lub złożeniem do sądu odpowiedniego wniosku.

\section{Bibliografia}

Dąbkiewicz K., Kilka uwag w kwestii art. 173 § 3 i 4 k.k.w., „Probacja” 2013, nr 1.

Dąbkiewicz K., Kodeks karny wykonawczy. Komentarz, Warszawa 2015.

Dąbkiewicz K., Zaskarżalność postanowień $i$ decyzji podejmowanych $w$ postępowaniu wykonawczym, „Probacja” 2012, nr 2.

Druk statystyczny MS-S10o za 2015 i 2016 rok.

Druk statystyczny MS-S10r za 2014, 2015 i 2016 rok.

Nowa Kodyfikacja Prawa Karnego 54, 2019

(C) for this edition by CNS 
Druk statystyczny MS-S40r za 2015, 2016 i 2017 rok.

Kalisz T., Skarga na decyzje organów wykonawczych. Tryb skargowy z art. 7 k.k.w., „Nowa Kodyfikacja Prawa Karnego” 7, 2001.

Kodeks karny wykonawczy. Komentarz, red. J. Lachowski, Warszawa 2018.

Lachowski J., Oczkowski T., Skarga skazanego w postępowaniu wykonawczym (art. 7 k.k.w.), „Przegląd Więziennictwa Polskiego” 2008, nr 61.

Lelental S., Kodeks karny wykonawczy. Komentarz, Warszawa 2010.

Lelental S., Kodeks karny wykonawczy. Komentarz, Warszawa 2012.

Postanowienie SA w Białymstoku z dnia 24 listopada 2014 roku, IIAKzw 2188/14, KZS 2015/2/81.

Postanowienie SA w Krakowie z 21 października 2015 roku, IIAKzw 965/15.

Postanowienie SA w Krakowie z 29 maja 2015 roku, IIAKzw 408/15.

Postanowienie SN z 4 kwietnia 2018 roku, VKK 66/18, LEX 2488988.

Postulski K., Decyzja kuratora w postępowaniu karnym wykonawczym, „Probacja” 2012, $\mathrm{nr} 2$.

Postulski K., Glosa do postanowienia s. apel. z dnia 5 listopada 2015 r., II AKzw 635/15, teza 5, LEX 2016, nr 302782/5.

Postulski K., Kodeks karny wykonawczy. Komentarz, Warszawa 2017.

Postulski K., Status skazanego w postępowaniu przed sądem, „Państwo i Prawo” 2010, nr $1-2$.

Rozporządzenie Ministra Sprawiedliwości z dnia 13 czerwca 2016 roku w sprawie sposobu i trybu wykonywania czynności przez kuratorów sądowych w sprawach karnych wykonawczych (Dz.U. z 2016 r. poz. 969).

Skręt R., Stasiorowski S., Sąowy kurator zawodowy w świetle nowelizacji Kodeksu karnego wykonawczego, „Probacja” 2012, nr 2.

Stasiak K., Kurator sadowy organem postępowania wykonawczego, [w:] Kuratela sadowa w Polsce. Analiza system. Księga pamiątkowa dedykowana doktorowi Tadeuszowi Jedynakowi, red. K. Stasiak, Toruń 2018.

Stasiak K., Wnioski sktadane przez kuratora dla dorostych, [w:] Zarys metodyki pracy kuratora sadowego, red. K. Stasiak, Warszawa 2018.

Ustawa z dnia 6 czerwca 1997 roku Kodeks karny wykonawczy (tekst jedn. Dz.U. z 2017 r. poz. 665 ze zm.).

Ustawa z dnia 6 czerwca 1997 roku — Kodeks postępowania karnego (tekst jedn. Dz.U. z 2016 r. poz. 1749 ze zm.).

Ustawa z dnia 16 września 2011 roku o zmianie ustawy — Kodeks karny wykonawczy oraz niektórych innych ustaw (Dz.U. z 2011 r. Nr 240, poz. 1431).

Uzasadnienie do Rządowy projekt ustawy o zmianie ustawy - Kodeks karny wykonawczy oraz niektórych innych ustaw — druk 3961, Sejm VI kadencji, http://orka.sejm. gov.p1/Druki6ka.nsf/wgdruku/3961 (dostęp: 11.02.2018).

Zarys metodyki pracy kuratora sadowego, red. K. Stasiak, Warszawa 2018. 


\section{The institution of admonition referred to in Art. 173 of the Executive Penal Code}

\section{Summary}

Article 173 of the Executive Penal Code provides for the possibility for the convicted person or the offender to receive a admonition from the probation officer as an alternative to his or her request to the court. In line with the intentions of the proposers of this solution, the purpose of the admonition is to discipline the convicted person (offender) to fulfil his or her obligations related to the probation period. In 2018, court superintendents throughout Poland granted more than 7,000 warnings, which means that on average, a court superintendent applies them twice a year. This article discusses the nature of legal warnings, their application and the possibilities of appeal. The article ends with conclusions.

Keywords: admonition, Executive Penal Code, probation officer, court, decision, complaint against probation officer's decision. 